\title{
Analysis on differences of carbon dioxide emission from cement production and their major determinants
}

\author{
Tianming Gao a, b, Lei Shen ${ }^{\text {a }}$, Ming Shen ${ }^{\text {a, b, * }}{ }^{\text {, Fengnan Chen }}{ }^{\text {a, b }}$, Litao Liu ${ }^{\text {a }}$, Li Gao ${ }^{\text {c, d }}$ \\ a Institute of Geographic Sciences and Nature Resources Research (IGSNRR), CAS, 11A Datun Road, Chaoyang District, Beijing 100101, China \\ ${ }^{\mathrm{b}}$ University of Chinese Academy of Sciences, Beijing 100049, China \\ c School of Economics and Management, China University of Geosciences, Wuhan 430074, China \\ ${ }^{\mathrm{d}}$ Institute of Policy and Management, Chinese Academy of Sciences, Beijing 100190, China
}

\section{A R T I C L E I N F O}

\section{Article history:}

Received 26 January 2014

Received in revised form

5 October 2014

Accepted 4 November 2014

Available online 13 November 2014

\section{Keywords:}

Cement production

$\mathrm{CO}_{2}$ emissions

Affecting factors

Reducing emissions

Method

\begin{abstract}
A B S T R A C T
Based on 15 production lines we surveyed in China, the widely accepted input and output methods were applied to compare the process emissions with CSI (Cement Sustainability Initiative), and IPCC (Intergovernmental Panel on Climate Change) default values. We found that the output method would magnify $\mathrm{CO}_{2}$ emissions from carbonate breakdown during clinker production. A reasonable method is to calculate carbonate content in raw meal using the $\mathrm{CaO}$ and $\mathrm{MgO}$ content in carbonate-containing material and their material ratio. Another finding is that the raw meals consumption recommended by CSI and CMBA (China Building Materials Academy) would enlarge and underestimate the calcining emissions, respectively. We applied the TC (total carbon) and LHV (lower heating value) methods for fuel emissions calculation and found that all of the samples' fuel emissions by the LHV method were higher than those by the TC method. Indirect emissions from different cement producing stages were also estimated by using regional electricity emission factor. In raw meal preparation and cement grinding stage, there were no differences in main production technologies, but in clinker production stage a remarkable difference appears. Replacing carbonate-containing materials with non-carbonate materials and changing clinker ratio are the main ways to reduce $\mathrm{CO}_{2}$ content in raw meal and process emissions. Lowering fossil fuel intensity, using clean energy and alternative fuel were strongly recommended for reducing cement energy emissions.
\end{abstract}

Crown Copyright $\odot 2014$ Published by Elsevier Ltd. All rights reserved.

\section{Introduction}

The cement industry is one of the most significant sources of greenhouse gases $(\mathrm{GHG})$ in particular with carbon dioxide $\left(\mathrm{CO}_{2}\right)$ emissions. This sector accounts for about $1.8 \mathrm{Gt}$ of $\mathrm{CO}_{2}$ emissions in 2006 (Barker et al., 2009), approximately 7\% of the total anthropogenic $\mathrm{CO}_{2}$ emissions worldwide (Deja et al., 2010). This percentage is rapidly increasing since cement production is expected to increase faster. The cement industry will still play a more significant role in the future development though it is a major source of pollution. Recently, one of key goals of the global environmental agenda is to reduce emissions so as to protect world climate

\footnotetext{
* Corresponding author. Institute of Geographic Sciences and Nature Resources Research (IGSNRR), CAS, 11A Datun Road, Chaoyang District, Beijing 100101, China. Tel.: +8610 64888073 13; fax: +861064889005.

E-mail address: gaoming0920@aliyun.com (M. Shen).
}

pattern. Ammenberg et al. (2015) discussed the extent of industrial symbiosis options can lead to reduced $\mathrm{CO}_{2}$ emissions. After then Feiz et al. (2015) presented a systematic approach for assessing measures to reduce $\mathrm{CO}_{2}$ emissions in cement industry. Control of thermo-chemical process emissions is significantly important to meet $\mathrm{CO}_{2}$ emissions limitations (Mikulčić et al., 2015). Using demolished inorganic building materials and waste concrete powder as cement substitute materials is a recycling method for recycled cement (Oh et al., 2014). There are various approaches to improve energy efficiency. However, reduce limestone in raw meal and change its chemistry are becoming increasingly important to lower process emissions.

In general, carbon emissions from cement industry depend on cement production and emission factors. There are two widely accepted methods for estimating $\mathrm{CO}_{2}$ emissions from cement production process. One is raw materials based (input) method; the other is defined as clinker based (output) method. The input method calculates calcinations $\mathrm{CO}_{2}$ emissions based on volume and 
carbonate content of raw materials consumed in cement production (Cement Sustainability Initiative-CSI, 2005; CSI, 2011), while the output method is based on volume and composition of clinker produced (CSI, 2005, 2011). In theory, the raw material and clinker based methods are equivalent. In practice, however, the input method requires more extensive data than the clinker based method, thus not widely applied and only used in few countries such as the United States and Japan (CSI, 2005). Some rough estimation methods are also used in the absence of relevant data or for convenience. According to the clinker-based methodology, the CSI (2011) estimated the default emission factor as $547 \mathrm{~kg} \mathrm{CO}_{2}$ for per ton clinker production. However, in the absence of specific data, a default emission factor of $520 \mathrm{~kg} \mathrm{CO}_{2} / \mathrm{t}$ clinker is recommended by Intergovernmental Panel on Climate Change (IPCC, 1996, 2006).

China is the biggest cement producer and $\mathrm{CO}_{2}$ emitter in the industry. The cement industry, accounting for $15 \%$ of total GHG emissions in China in 2009, is one of the main sectors to implement low carbon development (Wang et al., 2013). A life cycle inventory study on China cement industry is conducted by Li et al. (2014) to evaluate the environmental damages, including GHG, primary pollution and the hazardous air pollutants. Hu et al. (2014) selected two most common production processes in China to investigate material and energy use as well as pollutant emissions. Chen et al.'s (2015) study addressed pollutants generated by the cement industry in China, the impacts of these pollutants, and the potential for environmental improvement. Different estimations on cement production emissions of China vary significantly owing to different default emission factors. The Carbon Dioxide Information Analysis Center-CDICA (2013), for example, recommended $499 \mathrm{~kg} \mathrm{CO}_{2} / \mathrm{t}$ as emission factor to estimate China's cement production emissions. Wang (2008) adopted an emission factor of $425 \mathrm{~kg} \mathrm{CO}_{2} / \mathrm{t}$ to roughly estimate the process emissions from China's cement production in 2005 and 2007. Shen et al. (2014), using onsite surveys and sampling, developed a factory-level measurement for different types of clinker and cement production and classified the overall emission factors of cement production into three types (process emissions, combustion emissions and electricity emissions factors). Other scholar's estimations are listed in Table 1. Many scholars (Ke et al., 2013, 2012; Lei et al., 2011; Wang et al., 2013) estimated China's cement emissions with the default value. These studies' major advantage is increasing the energy efficiency in China's cement industry, yet they also have some weaknesses, which is they did not consider the historical improvement of clinker quality and the use of alternative resources in raw meal preparation. Nowadays most cement plants in China widely adopted new methods and technologies including non-carbonate sources, New Suspension preheater (NSP) kiln, waste heat recovery (WHR) power generation technologies and low clinker-to-cement ratio. As a result it is highly believed that the Chinese cement emission factors should be reviewed and corrected.

Above studies made significant contribution to $\mathrm{CO}_{2}$ emissions inventory for China's cement industry, yet we strongly argue some

\section{Table 1}

China's cement $\mathrm{CO}_{2}$ emission factor estimated by scholars $\left(\mathrm{kg} \mathrm{CO}_{2} / \mathrm{t}\right)$.

\begin{tabular}{llll}
\hline & Energy consumption & Calcining process & Total \\
\hline Zhu, 2000 & $367-393$ & 365 & $732-758$ \\
Worrell et al., 2001 & 467 & 415 & 883 \\
WBCSD, 2002 & - & - & $900-950$ \\
NDRC, 2004 & - & 374 & - \\
Cui and Liu, 2008 & $168(259)$ & 395 & $563(654)$ \\
Boden et al., 2009 & - & $496-507$ & - \\
Lei et al., 2011 & $248-336$ & 395 & $643-731$ \\
Wang, 2009 & 226 & 425 & 651 \\
\hline
\end{tabular}

Note: the numbers in parentheses are the clinker emission factors. existing limitations. First, the emissions factor value is not a fixed value which depends on the technology, equipments, fuels used and other factors. Due to the widely used steel slag and fly ash in raw meal preparation, the component of $\mathrm{CaO}$ and $\mathrm{MgO}$ from noncarbonate should be subtracted in clinker based method. Second, fuel emission factors, including electricity emission factors used in their studies, were not suitable for China's case. Third, previous studies just considered $\mathrm{CO}_{2}$ emissions accounting, but did not identify their key driving forces. Considering these shortcomings mentioned above, we aim to provide some Chinese empirical studies and analysis. In this study, 11 NSP kilns from 8 cement plants and 4 shaft kilns from 3 cement plants were surveyed in Guangdong province of China. According to these 15 samples, we compared the estimation results for cement production process using different $\mathrm{CO}_{2}$ calculating methods by IPCC, CSI, and other organizations. This study aims to evaluate the different estimation methodologies, understand their diversity in various estimation methodologies, identify the driving factors of $\mathrm{CO}_{2}$ emissions from cement production, and provide policy implications for decision makers for appropriate mitigation policies towards China's "2020 strategic reduction target ${ }^{1 "}$.

The next sections will examine how $\mathrm{CO}_{2}$ emissions are originated from cement industry and its amounts through various calculation methods, justify with onsite surveyed samples in Guangdong province which is a developed coastal area in China. Some main factors affecting cement emissions are also presented. The last section is our conclusions.

\section{2. $\mathrm{CO}_{2}$ emissions from cement industry and its calculating methods}

During the cement producing process, $\mathrm{CO}_{2}$ is emitted from three different sources. Combustion of fossil fuel and calcination of calcium carbonate in processing stage, are defined as direct emissions. An indirect amount of $\mathrm{CO}_{2}$ comes from electricity for raw materials transportation and electricity generating consumed by electrical motors and facilities. During the cement manufacturing process, almost $90 \%$ of $\mathrm{CO}_{2}$ is direct emissions, and $10 \%$ is from the convey of raw material and some other production processes (Mikulčić et al., 2013).

\subsection{Direct emissions}

\subsubsection{Process emissions}

Calcium oxide $(\mathrm{CaO})$ and magnesium oxide $(\mathrm{MgO})$ are the typical clinker composition, which account for $64-68 \%$ of the clinker weight. Limestone is a major raw material used in the production of cement. The typical limestone used in cement production has $75-90 \% \mathrm{CaCO}_{3}$ in raw meal. Most $\mathrm{CO}_{2}$ is produced in converting calcium carbonate $\left(\mathrm{CaCO}_{3}\right)$ and magnesium carbonate $\left(\mathrm{MgCO}_{3}\right)$ into $\mathrm{CaO}$ and $\mathrm{MgO}$. When temperature is above $900{ }^{\circ} \mathrm{C}$, the calcinations take place:

$\mathrm{CaCO}_{3} \rightarrow \mathrm{CaO}+\mathrm{CO}_{2} \uparrow$

At this stage, the $\mathrm{CO}_{2}$ leaves the materials, the raw meal losing over one third of its original weight. When temperature reaches $1300-1450{ }^{\circ} \mathrm{C}$, the reaction of clinkerisation takes place, parts of the material become liquid, forming nodules known as clinker.

\footnotetext{
${ }^{1}$ China promised to reduce carbon emission intensity per unit of gross domestic product (GDP) by $40-45 \%$, using 2005 as the benchmark year, and to increase the percentage of non-fossil fuels in the primary energy consumption to approximately $15 \%$ by 2020 .
} 


\subsubsection{Process emission calculating method}

Cement production is a complex crafts due to various materials and energy flows. So the $\mathrm{CO}_{2}$ emissions inventory for cement industry is also complicated. During the last two decades, many organizations and scholars (China Building Materials AcademyCMBA, 2011; CSI, 2005, 2011; IPCC, 1996, 2006; Ke et al., 2013; Netherlands Environmental Assessment Agency-PBL, 2008; Wang et al., 2013) have made many efforts on calculating $\mathrm{CO}_{2}$ emissions inventory in cement industry. These methods differ only in the range of operating boundaries, specific calculation methods for each emission process, and the specific $\mathrm{CO}_{2}$ emission coefficient. These are valuable sources of calculating cement production $\mathrm{CO}_{2}$ emissions. However, to determine whether these methods are scientific and applicable in China, we need to conduct empirical research and comparative studies first.

2.1.2.1. IPCC method. The IPCC provides three basic methodologies for estimating emissions from cement production, which focus on process emissions from carbonate minerals during the process of clinker production. And it is widely accepted and cited default emission factor is $510 \mathrm{~kg} \mathrm{CO} / \mathrm{t}$ clinker, without including $\mathrm{MgO}$ emissions.

In tier 1 method, emissions are calculated by estimating clinker production inferred from cement production data, correcting for imports and exports of clinker. The clinker based output method has been adopted by IPCC as tier 2 method for national GHG inventory calculations. It requires collection of clinker production data and information of the $\mathrm{CaO}$ content of clinker and fraction of $\mathrm{CaO}$ from carbonate. If a plant is deriving a significant fraction of $\mathrm{CaO}$ from a non-carbonate source (such as steel slag or fly ash), this component of $\mathrm{CaO}$ should be subtracted first in emissions estimation (IPCC, 2006). Tier 3 emission calculation is based on actual $\mathrm{CO}_{2}$ contents of carbonates, which requires full accounting of carbonates (species and sources). This method need ensure that all carbonate inputs (i.e., types, amounts, all sources) to the kiln are fully investigated, and repeat full investigation whenever there is any significant change in materials or processes. However, a large number of raw material inputs and the need of continuously chemical composition monitor make this approach impractical in many cement plants (CSI, 2011).

2.1.2.2. CSI clinker based method. CSI calculation method was based on the IPCC guidelines and has been applied by over 100 countries in their major cement plants. For the process emissions, CSI method presents two calculation methods: a carbonate mineral based method and a composition of clinker based method. The CSI clinker based method is basically the same with IPCC method, but considered the influence of $\mathrm{MgO}$ in clinker, bypass dust and cement kiln dust (CKD) in clinker production, and the influence of no-fuel carbon from raw material.

A small amount of $\mathrm{MgO}(1-2 \%)$ in clinker is desirable, because it acts as a flux (Van Oss and Padovani, 2002). Part of MgO may come from carbonate source. In IPCC tires 1 and 2 default emission factors might be underestimate as they do not include the $\mathrm{CO}_{2}$ emissions from the calcinations of $\mathrm{MgCO}_{3}$ (Ke et al., 2013). CSI (2005) suggested that calculating $\mathrm{CO}_{2}$ emissions from calcinations process is based on the $\mathrm{CaO}$ and $\mathrm{MgO}$ content in the clinker. Corresponding to IPCC default value, a default of $525 \mathrm{~kg} \mathrm{CO}_{2} / \mathrm{t}$ clinker should be used (CSI, 2005).

Emissions from fuel are emitted from two different sources: kiln fuels and non-kiln fuels. These fuels defined by CSI as conventional fuels and alternative fuels, mixed fuels and biomass fuels (CSI, 2011).CSI (2005) gave the emission factor of alternative fuels. CKD, TOC and indirect emissions from electricity consumption were also calculated and reported by CSI.
2.1.2.3. CBMA method. CBMA method was jointly developed by China Building Materials Academy (CBMA), China Business Council for Sustainable Development (CBCSD), Institute of Geographic Sciences and Natural Resources Research, CAS (IGSNRR,CAS), and China Clean Development Mechanism Fund (CCDMF), and approved by the China National Standardization Committee in 2013. This method took fully considerations of the emissions influence factors mentioned above into its calculation. It provides a basic $\mathrm{CO}_{2}$ calculation method for enterprises, especially the producers with alternative raw materials and alternative fuel, and a conversion factor (1.04) for coal ash added in clinker. However, this approach is based on the composition of $\mathrm{CaO}$ and $\mathrm{MgO}$ in clinker, instead of the carbonate content in raw material. This will expand emission factor, especially when there are many producers using steel slag and fly ash as raw material, in which $\mathrm{CaO}$ and $\mathrm{MgO}$ exist in the form of non-carbonate.

\subsubsection{Fuel emissions and calculating method}

It is widely recognized that there is an additional source of $\mathrm{CO}_{2}$ emissions from fuel burning during calcining process. Fuel is combusted to produce heat for the process of clinker production. The $\mathrm{CO}_{2}$ emissions form fuel combustion during the cement production process is influenced by the type of producing process, operating way, fuel used and the ratio of carbon content.

The approach is to calculate $\mathrm{CO}_{2}$ from conventional fuels based on fuel consumption, lower heating values (LHV) and the correspondent $\mathrm{CO}_{2}$ emission factors. Coal is the traditional fuel used in China's cement industry. Other types of fuels used include diesel, coke, coal gangue, fuel oil, as well as municipal wastes, while they shared only about $2.4 \%$ of the final energy consumption in 2009 (Ke et al., 2012). Missions from biomass alternative fuels are considered carbon-neutral. As a result, alternative fuel (AF) could reduce considerably fuel-related $\mathrm{CO}_{2}$ emissions in cement industry.

\subsection{Indirect emissions and calculating method}

Date of indirect emissions is useful to assess overall carbon footprint of an industry. Four categories of indirect emission were listed by CSI (2005). But, in our surveyed samples, external production of electricity consumed by cement producer is the only sources. The $\mathrm{CO}_{2}$ emissions from electricity consumed by cement production are estimated by using the annual national or regional average emission factors and power bought from external grid. Due to different technology and energy mix in different years and regions, emission factors of regional power grids may vary significantly (Lindner et al., 2013). In China, there are 7 power grids with different emission factors.

\section{Case studies: comparing cement emissions based on onsite samples in Guangdong Province of China}

Guangdong Province is the fourth largest cement producer in China. In 2010, 102 Mt of cement were produced, which accounted for $5.43 \%$ of China's cement production. There are 230 cement plants producing cement in complete manufacturing cycle, 60 cement grinding plants, of which include 51 NSP kilns with a clinker production capacity of $58.4 \mathrm{Mt}$, accounting for $61.5 \%$ of the total production capacity, and 430 other process lines with the production capacity of $37.1 \mathrm{Mt}$. In this study, 4 shaft kilns (abbreviated as S) and 11 NSP kilns (abbreviated as N) production lines were surveyed. These 8 NSP kiln plants are Taini yingde $(\mathrm{N}-1)$, Yingde hailuo (N-2), Guanying (N-3), Zhongcai hengda (N-4), Tapai longmen (N-5), Guanzhou yuebao (N-6), Guanzhou zhujiang (N-7), Meizhou longteng $(\mathrm{N}-8)$, and the other 3 shaft kiln plants are 
Heyuan hexing (S-1), Meizhou ganyuan (S-2), and Meixian hanjiang (S-3).

Generally, a cement production process can be divided into three main stages after mining and quarrying. This study involves crushing and grinding of raw materials, materials calcining in a rotary kiln, clinker cooling, mixing of the clinker with gypsum; and milling, storing and bagging of the finished cement (Fig. 1).

Detailed data collection forms were developed and used to collect information of onsite cement and clinker production, raw material and electricity consumption and energy use from the surveyed cement plants. The number of production lines at these plants, their clinker and cement production capacity and actual clinker and cement production quantity in 2012, energy used for per unit clinker and cement production, the alternatives of raw material and their composition were also collected. The systems datum are documented accordingly of continuous 12 months in 2012. Readings are taken repeatedly to minimize errors; and averaged values are employed in this paper. The composition of the raw materials, coal, and produced clinkers are similar to those of home and abroad Portland cement plants. The fuel intensity represents the energy efficiency and the level of China's cement industry. In addition, limestone, clay, shale, fly ash, coal, raw meal, clinker and cement outputs were also collected by a stainless steel spatula. These dry samples were collected from various points within the stockpiles and stored in zip locked plastic bags for analysis. All the collections and measurements are carried out during normal plant operations.

\subsection{Process emissions based on input and output methods}

At the calcining process, there are three sources of process $\mathrm{CO}_{2}$ emissions: $\mathrm{CO}_{2}$ from calcium carbonate breakdown, $\mathrm{CO}_{2}$ from nonrecycled $\mathrm{CKD}$ leaving the kiln system, and $\mathrm{CO}_{2}$ from organic carbon during pyro-processing of the raw meal (Wang et al., 2013). $\mathrm{CO}_{2}$ from carbonates can basically be calculated by raw material way issued by IPCC tier 3 which based on the volume and carbonate content of the raw meal consumed. But IPCC tier 3 is impractical in many cement plants. In general, the test carbonate content of raw material is a complex process. However, in many cement plants the homogenized mass flow of raw meal is routinely monitored including its chemical analysis for the purpose of process and product quality control. The testing of $\mathrm{CaO}$ and $\mathrm{MgO}$ content of raw material is a regular process. In typical cement plant, the carbonate rocks, such as limestone and dolomite, are the dominantly used raw

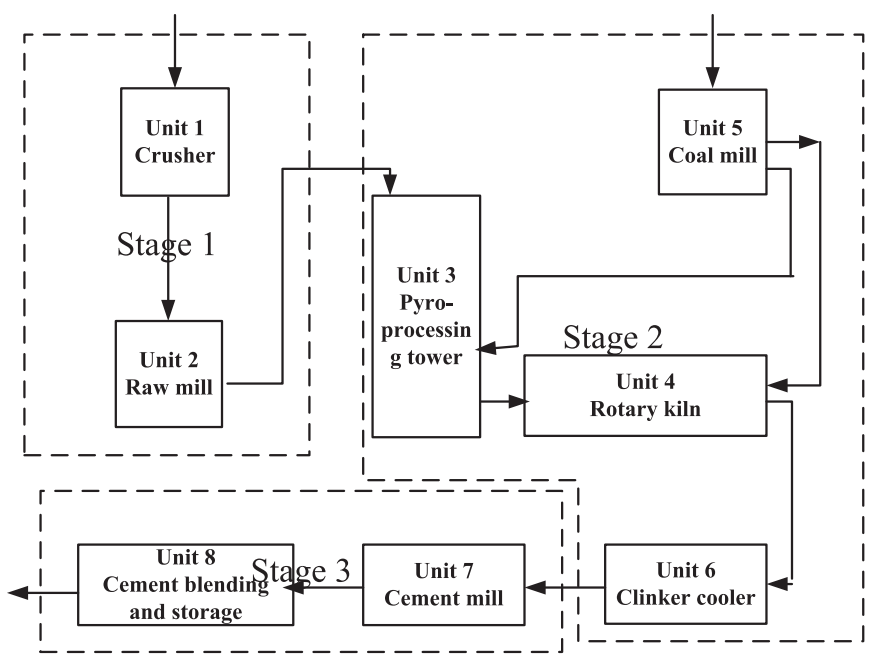

Fig. 1. The scope and system boundary of cement production. materials. From the analysis of Ma et al. (2005), Zuo (1981), and Fan et al. (2001), we know that there could be a carbonate component in these raw materials: clay, shale, sandstone, and other supplementary materials. Steel slag, magnesium slag and fly ash were widely used as raw materials in many Chinese cement plants. In these materials, the $\mathrm{CaO}$ and $\mathrm{MgO}$ exist not in the form of carbonate but non-carbonate. Therefore, we assume that $\mathrm{CaO}$ and $\mathrm{MgO}$ are all from carbonate minerals in carbonate-containing material.

Based on this assumption and raw material ratio, we could use the $\mathrm{CaO}$ and $\mathrm{MgO}$ content in carbonate-containing material and their material ratio to calculate $\mathrm{CO}_{2}$ content in raw meal (Eq. (1)).

$R a_{\mathrm{CO}_{2}}=\sum\left(R c a_{i} \times r_{i} \times \frac{44}{56}+R m g_{i} \times r_{i} \times \frac{44}{40}\right) \quad(i=1,2,3 \ldots)$

where $R a_{\mathrm{CO}_{2}}$ represents $\mathrm{CO}_{2}$ content in raw meal, \%; $R c a_{i}, R m g_{i}$ represents calcium carbonate and magnesium carbonate content in raw material $i, \% ; r_{i}$ represents the proportions of raw material $i$ in raw meal, \%; 44/56, 44/40 represent $\mathrm{CO}_{2}$ content in calcium carbonate and magnesium carbonate; $i=1,2,3 \ldots$ represents carbonate material species. Then we analyzed the collected raw meal samples from these production lines, and their $\mathrm{CO}_{2}$ content are showed in Fig. 2. Comparing the content value of calculated results to the testing samples (Fig. 2), we found that the calculated $\mathrm{CO}_{2}$ content is very close to the actual value of raw meals, the calculated and testing average values are $34.78 \%$ and $34.80 \%$ for NSP kilns and $31.33 \%$, and $31.55 \%$ for shaft kilns. As a result, we could use $\mathrm{CaO}$ and $\mathrm{MgO}$ content in carbonate-containing material and their material ratio to calculate the carbonate content in raw meal. The $\mathrm{CO}_{2}$ content from the raw meal method is lower than the clinker based method, and can better reflect the actual carbon dioxide emissions in clinker/cement production.

The calcinations $\mathrm{CO}_{2}$ emission factor is based on determining the amount of raw material consumed for per ton clinker production and the carbonate source content in raw meal. Raw meal clinker mass ratio is determined by the types of raw materials and composition, fuels ash and the quality of clinker. Since the temperature in clinker kiln is about $1300-1450{ }^{\circ} \mathrm{C}$, in theory carbonate decomposition reaction is complete. But actually, the carbonate material is incompletely calcined in the outdate kilns, due to the uneven heating, insufficient amount of air into the kiln and uneven air distribution, etc. In dry process, the proportion of $\mathrm{CO}$ in exhaust gas emitted by the kiln was negligible (Qiu et al., 2012). This means that the oxidation reaction was complete in this craft. But in other process, especially the shaft kiln, the CO proportion varies at $1.3 \%-$ $1.6 \%$ according to the different calcination technologies (National Building Materials Test Center-NMBTC and NMBTC CMBA, 2007). In

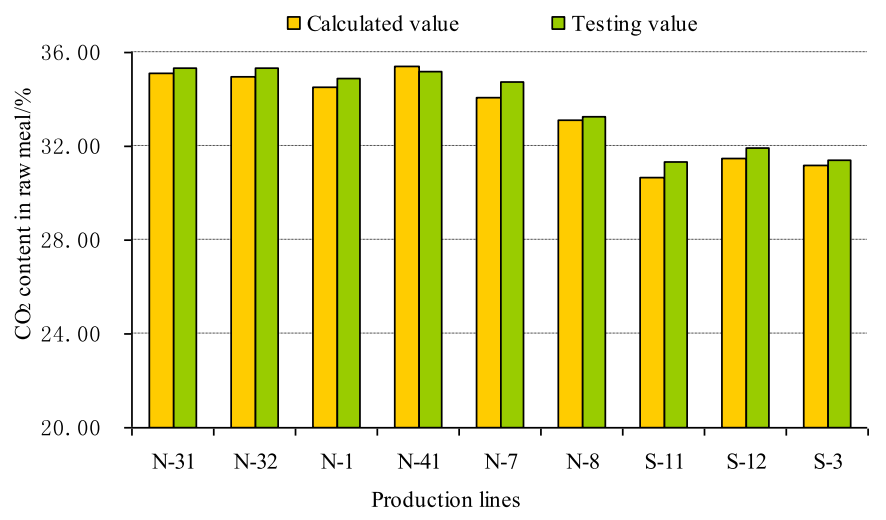

Fig. 2. Compare the calculated and testing $\mathrm{CO}_{2}$ content in collected real meals. 
the absence of data, a default value of $1.4 \%$ shall be used for incomplete combustion in outdate kilns.

Based on the $\mathrm{CO}_{2}$ content in the raw meals from the 15 onsite cement plants, and their raw meal consumed in each clinker production lines, we calculated their process $\mathrm{CO}_{2}$ emissions from clinker production. As Fig. 3 shows, the production line S-11 gives the lowest estimate for process $\mathrm{CO}_{2}$ emissions ( $498.17 \mathrm{~kg} / \mathrm{t}$ clinker) from clinker production, while the clinker production line $\mathrm{N}-31$ gives the highest estimate (537.31 kg/t clinker). Given the large discrepancies between the two production lines, the proportion of limestone in raw meal is very different. We note that based on the raw materials method the average process $\mathrm{CO}_{2}$ emissions ( $522.66 \mathrm{~kg} / \mathrm{t}$ clinker) from all NSP kilns is very close to CSI default value $(525 \mathrm{~kg} / \mathrm{t}$ clinker). The relative uncertainty of the estimation of the process $\mathrm{CO}_{2}$ emission from the surveyed NSP cement plant is 4.31-6.46\%. But for the shaft kiln, their process emissions (507.46 kg/t clinker) are lower than the default values. And the relative uncertainty of the estimation for shaft cement plant is 2.76-4.14\%. To compare, the calcination emissions estimation based on clinker method are also listed in Fig. 3. It clearly presents that almost all of the process emissions from production lines by raw materials are lower than those by the clinker method. Their difference is that the $\mathrm{CaO}$ and $\mathrm{MgO}$ from clinker is not all from carbonate materials. Therefore, we believe that the clinker method will exaggerate $\mathrm{CO}_{2}$ emissions from $\mathrm{CaCO}_{3}$ and $\mathrm{MgCO}_{3}$ breakdown during clinker production. According to the 15 sample production lines, the process emissions based on raw material is about $13 \mathrm{~kg}$ and $11 \mathrm{~kg}$ lower than clinker method for NSP and shaft kilns, respectively (Fig. 3).

To produce certain quality clinker, the materials putting into the raw meals are defined within a certain extent. The four variables, limestone, clay, shale and iron ore are interacted in raw meal production. These four parameters are assumed as independent with each other for the local sensitivity analysis. Limestone content in raw meal representing the variable was taken into account during the sensitivity calculations. Because we have no more data to describe the distribution of the process emissions, computing sensitivities is based on a design of experiment, and we assume a $2 \%$ variation based on the basic data of $83.90 \%$ for the parameter limestone content in raw meal. Table 2 shows that if the limestone content in raw meal decreased from $83.91 \%$ to $82.22 \%$, the clinker quality will present a decline ( $K$ was decreased from 0.89 to 0.85 ), and the process emission will be reduced by $12.36 \mathrm{~kg}$ for per ton clinker production. While, if the limestone content in raw meal increased by $2 \%$ (up to $85.17 \%$ ), the process emission factor will lift up to $531.9 \mathrm{~kg}$. The data show linear regression plots created between limestone content in raw meal and process emission factors
Table 2

Sensitivity of limestone content in raw meals responses to the process emissions.

\begin{tabular}{llllll}
\hline $\begin{array}{l}\text { Limestone } \\
\text { content } \\
(\%)\end{array}$ & $\begin{array}{l}\text { Chang } \\
\text { rate } \\
(\%)\end{array}$ & $\begin{array}{l}\text { Limestone } \\
\text { saturation } \\
\text { coefficient } \\
(K)\end{array}$ & $\begin{array}{l}\text { Raw meal } \\
\text { intensity } \\
(\mathrm{kg} / \mathrm{t} \text {-clinker })\end{array}$ & $\begin{array}{l}\mathrm{CO}_{2} \\
\text { content } \\
\text { in raw } \\
\text { meal }(\%)\end{array}$ & $\begin{array}{l}\text { Process emissions } \\
\left(\mathrm{kg} \mathrm{CO}_{2} / \text { t-clinker }\right)\end{array}$ \\
\hline 85.585 & 2 & 0.919 & 1500 & 0.355 & 531.9 \\
85.167 & 1.50 & 0.914 & 1501 & 0.354 & 530.7 \\
84.752 & 1 & 0.909 & 1499 & 0.353 & 528.6 \\
84.324 & 0.50 & 0.899 & 1498 & 0.351 & 526.3 \\
83.905 & 0 & 0.889 & 1494 & 0.35 & 522.5 \\
83.484 & -0.50 & 0.869 & 1488 & 0.348 & 518.2 \\
83.061 & -1 & 0.864 & 1486 & 0.347 & 515.7 \\
82.639 & -1.50 & 0.859 & 1484 & 0.346 & 513.1 \\
82.216 & -2 & 0.849 & 1481 & 0.345 & 510.2 \\
\hline
\end{tabular}

$(y=6.380 x-51.20)$. The $R_{2}$ values for this linear regression line shows that the limestone content in raw meal account for approximately $98.1 \%$ of the variance in process emissions. This suggests that the process emissions have the highest impact on the limestone content in raw meal if all the parameters are varied within a certain data range.

\subsection{Fuel emissions based on LHV and TC method}

The LHV and default emission factors for coal, fuel oil and natural gas were first from IPCC (1996) and corrected by the 2006 IPCC guidelines. CSI (2011) recommended companies to use plant- or country-specific emission factors if reliable data are available. This emission factor of fuels shall be based on the total carbon (TC) content. Direct calculation of emissions based on fuel consumption and fuel carbon content is acceptable given that material variations in the composition of the fuel, and especially its water content, are adequately accounted for (CSI, 2011).

Coal is the traditional fuel used in China's cement industry. And the share of alternative fuel (AF) is negligible. Just as showed in the collected cement plants, all coals of cement plants are used as clinker production. We compared the fuel emissions in clinker production based on LHV and TC methods. As shown in Fig. 4, all of the fuel emissions based on LHV method are higher than those on TC method. Their gaps fall into the ranges of $0.59-74.81 \mathrm{~kg}$ for per ton clinker production. In production line $\mathrm{N}-51$, the emissions from both methods are much approximate, while for production lines $\mathrm{N}$ 41 there is a difference about $74.81 \mathrm{~kg}$ in them. TC content of coal is an important source of heat. LHV of coal is determined by ash, volatile and moisture in dry basis. Therefore, LHV value is closely related to TC content and depends on other factors. In clinker

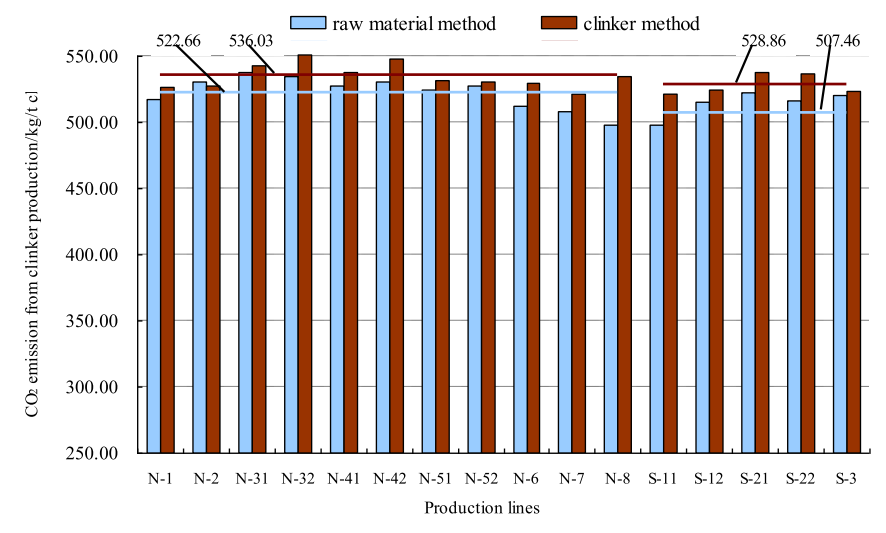

Fig. 3. Process emissions form clinker production based on raw materials and clinker method.

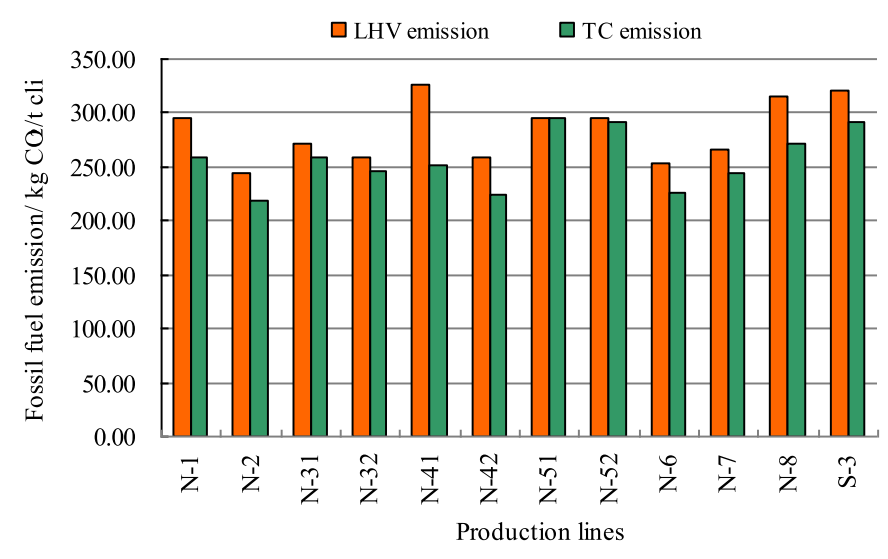

Fig. 4. Fossil fuel emissions in clinker production based on LHV and TC method. 
production, the $\mathrm{CO}_{2}$ emission factors of fuels should always be determined by the TC content. Thus, keeping the fuel consumption constant, and increasing the TC content in fuel, the fuel emission from the clinker production will increased at the same rate, and vice versa. According to TC method, the production line $\mathrm{N}-2$ gives the lowest estimate $\left(218.29 \mathrm{~kg} / \mathrm{t}\right.$ clinker) for fuel $\mathrm{CO}_{2}$ emissions, while $\mathrm{N}-51$ gives the highest estimate $(295.36 \mathrm{~kg} / \mathrm{t}$ clinker). The relative uncertain range of the estimation for the fuel $\mathrm{CO}_{2}$ emission is larger $(17.56 \%-26.35 \%)$ than the process emissions $(4.31 \%-$ $6.46 \%)$, due to the difference of production technologies and operated way.

\subsection{Indirect emissions based on Guangdong electricity grid emission factors}

Different countries usually adopt the same method in the calculation of $\mathrm{CO}_{2}$ emissions from purchased electricity, which is based on power consumption and electricity carbon emission factors excluding electricity lost in transport and distribution (United States Environmental Protection Agency-EPA, 2008). Fossil fuel based electricity production directly emits a large amount of $\mathrm{CO}_{2}$. In China, fossil fuel fired thermal power contributes more than $81 \%$ of the total electricity production and coal is the main fossil fuel for thermal power (National Bureau of Statistics-NBS, 2012a). Fired thermal power also dominates the electricity production in Guangdong province of China, but its proportion (79.35\%) is lower than national average (NBS, 2012b). Therefore, the electricity emission factor (0.9344) (National Development and Reform Commission-NDRC, 2012) is lower than national emission factor. And the indirect emissions show an exact linear relationship with electricity consumption.

The electricity used for cement production is mainly purchased from the regional grid, but some Chinese cement plants use waste heat recovery (WHR) power generation technologies to selfgenerate electricity. This technology is widely used for the NSP kiln in China. In the onsite 11 NSP kilns lines, 9 of them are the WHR power generation system which recovers the energy in waste heat and does not consume additional fossil fuels thus reduces the total energy consumption and $\mathrm{CO}_{2}$ emissions. Therefore the electricity consumed from the WHR power generation should be excluded while evaluating indirect emissions.

According to the electricity emission factor in Guangdong, we estimated the electricity emissions of the collected samples at different cement production stages. According to Fig. 5, we found that the electricity consumption range at raw meal preparation stage is from 23.14 to $38.39 \mathrm{KWh}$ per ton clinker for both of the main production technology. Their average indirect emission factor at this stage is about $26.33 \mathrm{~kg} \mathrm{CO} / \mathrm{t}$ clinker. At clinker calcining stage, however, the amount of electricity consumption has significant discrepancies. For NSP kilns the average electricity consumption is about $34.51 \mathrm{KWh}$, and its indirect emission factor is $32.25 \mathrm{~kg}$. For shaft kilns, the electricity consumption is $17.84 \mathrm{KWh}$ and indirect emissions factor is $16.66 \mathrm{~kg}$, which are almost half of NSP kilns' emissions. This discrepancy is resulted from the clinker movement in NSP kilns by power engine while shaft kilns depend on gravity. Cement grinding is the most electricity intensity stage, which used up $36.17 \mathrm{KWh}$, about $33.79 \mathrm{~kg} \mathrm{CO}$ emissions for grinding per ton cement. Other emissions from electricity are about $2.9 \mathrm{~kg} \mathrm{CO}_{2} / \mathrm{t}$ clinker in the surveyed samples. For the WHR generation system in NSP kilns, there were about 28.45 KWh electricity produced for per ton clinker production, meaning that $26.58 \mathrm{~kg} \mathrm{CO}_{2}$ was saved. The electricity emissions range from the shaft production lines is from $58.17 \mathrm{~kg} / \mathrm{t}$ cement to $63.76 \mathrm{~kg} / \mathrm{t}$ cement. The relative uncertainty of the estimation of the indirect $\mathrm{CO}_{2}$ emission by the onsite shaft cement plant is $5.98-8.98 \%$. Whatever the application of the WHR power generation technologies in the NSP cement plant, the uncertainty of indirect emissions falls into the range of $18.62 \%-27.93 \%$.

\section{Main factors affecting cement emissions}

\subsection{Factors affecting the process emissions}

\subsubsection{Raw meal consumed}

The process emissions with input method are determined by raw meal consumed and its carbonate content. Due to the absence of better data, a default of $1.55 \mathrm{t}$ raw meal/t clinker should be used (CSI, 2011). And in the CBMA method, a default value 1.04 was used as conversion factors of coal ash added in clinker. Plant-specific raw meal to clinker ratios should exclude the ash content of the fuels used, to avoid double counting (CSI, 2011). According to the principle of mass balance, we get the calculation method for raw meal clinker mass ratio. It is expressed in Eq. (2):

$r_{a}=\frac{1-C_{c l} \times A_{c}}{1-R_{l}}$

Here, $r_{a}$ represents raw meal clinker mass ratio; $C_{c l}$ represents coal consumption (dry) for per ton clinker production, $t ; A_{c}$ represents ash content of coal, \%; $R_{l}$ represents ignition loss of raw meal, \%. According to the equation and the composition of fuel and raw meal, we calculated the plant specific raw meal clinker mass ratio of the surveyed samples (Fig. 6). Fig. 6 provides summary information on raw meal consumed for production of pre ton clinker in the 15

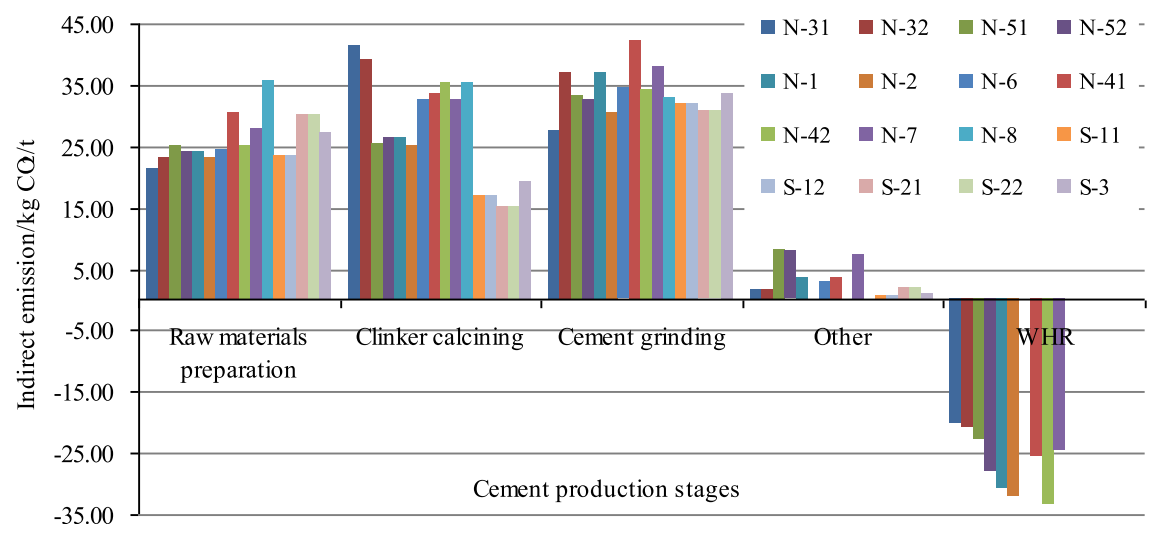

Fig. 5. Indirect emissions from cement production stages in the collected samples. 


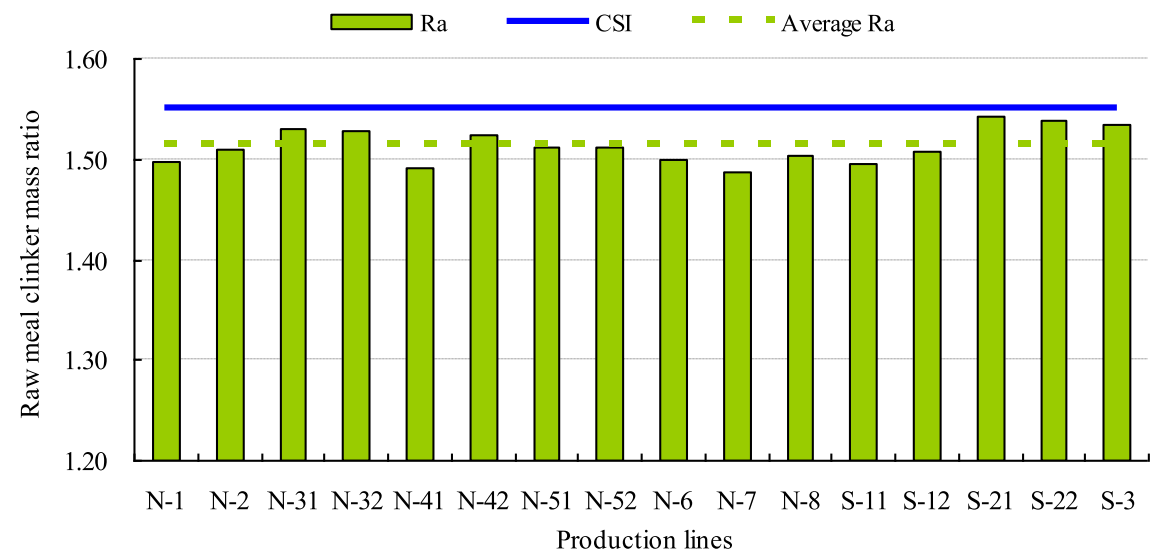

Fig. 6. Raw meal clinker mass ratio in surveyed production lines.

surveyed plants in Guangdong province. Production line S-21 consumed the highest amount of raw meal (1.542 t) in the production of per ton clinker, whereas production line N-7 had the lowest raw meal intensity $(1.486 \mathrm{t})$. The all plant specific raw meal clinker mass ratio in surveyed production lines was lower than the CSI default value (Fig. 6). Their average raw meal clinker mass ratio is 1.5132 (Fig. 6).

According to the coal and raw meal consumed, we calculated the amount of coal ash mixed in the clinker in the surveyed NSP kilns samples. The proportion of coal ash added into clinker is listed in the Table 3 . We note that coal ash added in clinker is determined by coal consumption and its ash content. Production line $\mathrm{N}-8$ is the biggest one, which mixed about $40.75 \mathrm{~kg}$ coal ash into clinker, whereas only $22.20 \mathrm{~kg}$ coal ash was added in clinker in production line N-31. The average coal ash added in clinker in the collected NSP kilns is about $30.34 \mathrm{~kg}$, accounting for $3.04 \%$ of per ton clinker. This proportion is less than the CMBA method's default value (1.04) $4 \%$. This means that less raw meal was consumed for per ton clinker based on the CMBA method, and less process emissions were emitted.

\subsubsection{Carbonate content in raw meal}

Another important reason to affect calcining $\mathrm{CO}_{2}$ emissions is the carbonate source content in raw meal, which depends on the carbonate content in the carbonate-containing materials and their share in raw meal. Siliceous and ferrous materials share $10-20 \%$ of raw meal, and carbonate content in these materials is negligible. Thus, replace siliceous and ferrous materials with coal ash, sulfuric acid residue, copper slag or lead slag to reduce process emissions is not significant. Their reduction potential is from $0.49 \mathrm{~kg}$ to $6.92 \mathrm{~kg} \mathrm{CO} / \mathrm{t}$ clinker, accounted for $0.01 \%-1.27 \%$ of the process

Table 3

Quantity and proportion of coal ash added in to pre ton clinker.

\begin{tabular}{lllll}
\hline $\begin{array}{l}\text { Production } \\
\text { lines }\end{array}$ & $\begin{array}{l}\text { Coal } \\
\text { consumption/kg }\end{array}$ & $\begin{array}{l}\text { Ash } \\
\text { content/\% }\end{array}$ & $\begin{array}{l}\text { Coal ash } \\
\text { added/kg }\end{array}$ & $\begin{array}{l}\text { Share of } \\
\text { clinker/\% }\end{array}$ \\
\hline B-1 & 153.71 & 24.24 & 37.27 & 3.73 \\
B-2 & 123.02 & 21.50 & 26.45 & 2.64 \\
B-31 & 135.70 & 16.36 & 22.20 & 2.22 \\
B-32 & 132.45 & 17.73 & 23.48 & 2.35 \\
B-41 & 151.24 & 24.17 & 36.56 & 3.66 \\
B-42 & 134.40 & 24.17 & 32.48 & 3.25 \\
B-51 & 138.98 & 22.60 & 31.41 & 3.14 \\
B-52 & 137.53 & 22.78 & 31.33 & 3.13 \\
B-6 & 124.86 & 21.75 & 27.16 & 2.72 \\
B-7 & 130.31 & 19.73 & 25.71 & 2.57 \\
B-8 & 137.43 & 29.65 & 40.75 & 4.07 \\
Average & - & - & 30.44 & 3.04 \\
\hline
\end{tabular}

emissions because of the different proportion of siliceous and ferrous materials in raw meal in the surveyed plants. So, using alternative materials of limestone is the main way to decrease $\mathrm{CO}_{2}$ emissions from raw materials decomposition. Bauxite, calcium carbide residue (CCR), steel slag, magnesium slag are the main noncarbonate materials to replace limestone. A future challenge of the cement industry is to use more alternative raw materials originating as byproducts from other industries or directly from other waste streams.

4.1.2.1. The reduction potential of replacing limestone by CCR. The properties of CCR cements were approved when the raw materials replaced by CCR (Krammart and Tangtermsirikul, 2004; Rattanashotinunt et al., 2013). In China there are more than 20 of the carbide slag cement production lines in production or under construction, the annual clinker production capacity is about 11.5 Mt. Based on a typical carbide slag producers, we design 5 ingredients programs to evaluate their process emissions reduction capability (Table 4). From Table 4, we know that with the increased incorporation of CCR, the reduction capability of process emissions from $110.95 \mathrm{~kg}$ increase to $401.83 \mathrm{~kg}$ per ton clinker by the incorporation of CCR from $15 \%$ to $60 \%$. This shows that CCR cement has a significant process emissions reduction capacity. Thus, we should fully utilize the $20 \mathrm{Mt}$ CCR as a by-product of the acetylene gas production.

4.1.2.2. Reduction potential by sulphoaluminate cement production. The manufacture of Ordinary Portland Cement (OPC) produces large amounts of $\mathrm{CO}_{2}$ mainly due to the high calcium carbonate content of raw meal. While calcium sulphoaluminate cement production demands less limestone in the raw feed, a lower burning zone temperature, and ease of cement grinding due to higher clinker porosity (Martín-Sedeño et al., 2010). So, sulphoaluminate cement represents a low $\mathrm{CO}_{2}$ alternative to OPC, mainly because they generate lower $\mathrm{CO}_{2}$ emissions in the clinkering process and grinding (Pelletier-Chaignat et al., 2012). Calcium sulphoaluminate cements have been used in China for about 40 years, but their development and use in other countries is not widespread currently.

Chemical composition of a typical sulphoaluminate cement producer is listed in Table 5, which shows that the ratio of limestone and bauxite is 48:52 in raw meal. The process emission in this cement plant is $271.52 \mathrm{~kg}$ for per ton clinker, which is $250 \mathrm{~kg}$ less than OPC. Sulphoaluminate cement manufacture in a modern cement plant can give $\mathrm{CO}_{2}$ emissions reductions of up to $35 \%$ per mass of cement produced, relative to OPC (Martín-Sedeño et al., 2010). 
Table 4

Different CCR cement ingredients programs and their reduction capability.

\begin{tabular}{|c|c|c|c|c|c|c|c|}
\hline Program & $\mathrm{CCR} / \%$ & Limestone/\% & Sandstone/\% & Clay $/ \%$ & Iron ore $/ \%$ & Process emissions $/ \mathrm{kg} \mathrm{CO} / \mathrm{t}$ clinker & Reduction capability/\% \\
\hline$A_{1}$ & 0.00 & 86.21 & 3.9 & 8.79 & 1.1 & 527.89 & 0 \\
\hline $\mathrm{A}_{2}$ & 15.00 & 70.41 & 3.86 & 9.42 & 1.31 & 416.94 & 21.02 \\
\hline $\mathrm{A}_{3}$ & 30.00 & 54.82 & 6.29 & 7.19 & 1.7 & 314.24 & 40.47 \\
\hline $\mathrm{A}_{4}$ & 45.00 & 39.30 & 8.69 & 4.91 & 2.1 & 218.37 & 58.63 \\
\hline $\mathrm{A}_{5}$ & 60.00 & 23.40 & 8.70 & 5.55 & 2.35 & 126.06 & 76.12 \\
\hline
\end{tabular}

\subsubsection{Adjusting clinker ratio value}

The quality of clinker is determined by limestone saturation coefficient $(\mathrm{KN})$, silicic ratio $(\mathrm{N})$ and aluminum oxide ratio $(\mathrm{P})$, whose value is based on the content of $\mathrm{SiO}_{2}, \mathrm{Al}_{2} \mathrm{O}_{3}, \mathrm{CaO}$, and $\mathrm{Fe}_{2} \mathrm{O}_{3}$ in clinker. $\mathrm{KN}$ can vary within a certain range (0.85-0.95). Moderately lowering $\mathrm{KN}$, less raw meal is consumed, less resources is demanded and less carbon emissions is emitted. If the $\mathrm{KN}$ decreased from 0.95 to 0.88 , the content of $\mathrm{CaO}$ in clinker will decreased from $68 \%$ to $64 \%$. This means that $\mathrm{CO}_{2}$ emissions from per ton clinker produced will be reduced by about $30 \mathrm{~kg}$ (Liu and $\mathrm{Li}$, 2010).

\subsection{Factors affecting the fuel emissions}

\subsubsection{TC content in fossil fuel and carbon oxidation factor}

TC content of fuel primary based on carbon content, but which also contain varying amounts of hydrogen, oxygen, nitrogen, sulfur and other elements. Tu et al. (2003) studied the correlation between fixed carbon and carbon content of anthracite coal, which value varied from 0.993 to 0.999 . TC in all kiln fuels should be treated as fully oxidized, due to very high combustion temperatures and long residence time in kilns and no, or minimal, residual carbon found in clinker (CSI, 2011).

The default carbon content and carbon oxidation factor for fuels was estimated by IPCC (2006). Many fossil fuels, such as fuel oil, natural gases are lower carbon content and $\mathrm{CO}_{2}$ emissions per $\mathrm{MJ}$ of energy than coal. Natural gas and fuel oil with around $38.5 \%$ and $17.2 \%$ less $\mathrm{CO}_{2}$ emissions per GJ compared with the coal (Pardo et al., 2011). So, using other fossil fuel rather than coal is a way to reduce fuel $\mathrm{CO}_{2}$ emissions in cement industry.

\subsubsection{Fuel intensity}

The main factors determining energy consumption in the cement industry are the structural shifts between kiln types, the kiln efficiency improvement, and the sophistication of kiln technologically. The fuel intensities of shaft kilns span a wide range, from 110 to more than $220 \mathrm{kgce} / \mathrm{t}$ clinker, depending on the levels of mechanization and operation skills.

NSP kilns differ from shaft kilns is because the existence of preheater or pre-calciner unit. Pre-heater towers consist of a series of vertical cyclone chambers which allow part of the heat of the exhausting gases of the kiln to be recovered. The energy consumption of kilns with suspension pre-heaters is much smaller than previous kilns. Pre-calciner kilns have an extra combustion

Table 5

Chemical composition of a typical sulphoaluminate cement producer.

\begin{tabular}{llrrrrrl}
\hline & Loss & $\mathrm{SiO}_{2}$ & $\mathrm{Al}_{2} \mathrm{O}_{3}$ & $\mathrm{Fe}_{2} \mathrm{O}_{3}$ & $\mathrm{CaO}$ & $\mathrm{MgO}$ & $\begin{array}{l}\text { Ratio of } \\
\text { raw material }\end{array}$ \\
\hline Limestone & 42.13 & 1.63 & 0.64 & 0.35 & 53.99 & 0.3 & 48 \\
Bauxite & 14 & 7.79 & 69.85 & 2.19 & 1.25 & 0.4 & 52 \\
Raw meal & 27.50 & 4.83 & 36.63 & 1.31 & 26.57 & 0.35 & \\
Coal ash & - & 34.22 & 22.63 & 9.36 & 19.48 & 2.06 & \\
Clinker & - & 7.35 & 51.07 & 2.17 & 35.37 & 0.72 & \\
\hline
\end{tabular}

chamber installed between the pre-heater and the kiln. This precalciner chamber consumes $60 \%$ of the fuel used in the kiln, and $80-90 \%$ of the calcination takes place there. This reduces energy consumption by $8-11 \%$ (Ali et al., 2011). Table 6 shows specific thermal energy consumption for different types of clinker manufacturing process. Energy management and process control system, kiln combustion system improvement, waste heat recovery were mainly used for improving kiln efficiency, and they saved 24.6\% energy comparing 2009 to 1990 in China's cement industry (Xu et al., 2012).

\subsubsection{AF used for reduction fuel emissions}

Due to the increased environmental awareness, cement plant operators are starting to use AF. The use of AF for cement clinker production is crucially important to the reduction of fuel emissions in cement manufacturing. AF has been used broadly. Mokrzycki and Uliasz-Bocheńczyk (2003) classified AF into three basic groups: gas (e.g., landfill gas, pyrolytic gas, and biogas), liquid (e.g., used oils and solvents), and solid (tires, wood waste, plastics, meat and bone animal meal (MBM), municipal solid waste (MSW), sewage sludge (SS) and textiles). MSW, MBM and SS are the most widely used AF in the EU cement industry (Aranda Usón et al., 2013). Using these $\mathrm{AF}$ as substitute fuel helps in saving conventional fuels and was accepted as renewable fuel energy sources. As biomass fuels, they help the cement plant reduce its $\mathrm{CO}_{2}$ conventional fuel emissions.

4.2.3.1. Municipal solid waste (MSW). MSW has become a common AF in cement industry. There are notable different ash, chlorine, sulfur, and water contents among MSW according to different sources. Their different physical and chemical properties can cause difficulties in the kiln combustion process if MSW is unsorted. Rovira et al. (2010) performed a study to analyze the effects of increasing the substitution ratio of MSW in a conventional fuel. By investigating the effect of MSW combustion in cement calcining system, the performance of clinker and cement, and the environment impact, the suitable rate of heat replaced by MSW disposing in NSP kilns is up to 30\% (Wang, 2006). It means that a reduction of $30 \%$ emissions from fossil fuels has been achieved.

4.2.3.2. MBM replace of coal. Gulyurtlu et al. (2005) performed several tests with different $\mathrm{MBM} /$ coal ratios to determine the influence of various MBM parameters on the process of cocombustion with coal. The reduction of $\mathrm{CO}_{2}$ emissions was evident when the ratio of MBM increased. Gulyurtlu et al. (2005) illustrated that the $\mathrm{CO}_{2}$ emissions from MBM was only about two-thirds from coal if the coal was fully replaced by MBM. Cascarosa et al. (2011) showed that increasing MBM content raised the production of $\mathrm{H}_{2}$ but tended to decrease $\mathrm{CO}_{2}$ and $\mathrm{CH}_{4}$. Another important aspect we need consider is the $\mathrm{NO}_{x}$ emissions increased. The test of using leather as an alternative fuel was carried out in China. And the result showed that 1 ton leather can replace 0.77 ton coal (Zhang, 2008). While in the production practice, the $15 \mathrm{~kg}$ coal was replaced by $30 \mathrm{~kg}$ leather, and the emissions reduction from the mixed fuels was $39 \mathrm{~kg}$ than the parent coal, accounting for $13.73 \%$ of the fuel emissions (Zhou et al., 2009). 
Table 6

Specific thermal energy consumption of a kiln process.

\begin{tabular}{|c|c|c|}
\hline Kiln process & Thermal energy consumption (Gj/t clinker) & Coal consumption (kgce/t clinker $)^{\mathrm{a}}$ \\
\hline Wet rotary kiln & $5.86-6.28$ & $199.73-214.04$ \\
\hline Dry long rotary kiln & 4.60 & 156.78 \\
\hline Dry long rotary kiln with 1 -stage cyclone preheater & 4.18 & 142.47 \\
\hline Dry long rotary kiln with 2-stage cyclone preheater & 3.77 & 128.49 \\
\hline Dry long rotary kiln with 3-stage cyclone preheater & 3.55 & 121.00 \\
\hline Dry long rotary kiln with 4-stage cyclone preheater & 3.14 & 107.02 \\
\hline $\begin{array}{l}\text { Dry long rotary kiln with 4-stage cyclone preheater, } \\
\text { calciner and high efficiency cooler }\end{array}$ & 3.01 & 102.59 \\
\hline $\begin{array}{l}\text { Dry long rotary kiln with 4-stage cyclone preheater, } \\
\text { calciner and high efficiency cooler }\end{array}$ & $<2.93$ & 99.86 \\
\hline
\end{tabular}

\footnotetext{
a Author's calculation.
}

Source: Ali et al. (2011)

4.2.3.3. Sewage sludge (SS). Normally, SS is placed in the main furnace of the cement kiln and burned as a fuel. At the same time the residual non-combustible components of the sludge are used as raw materials in cement production. In addition to moisture content, but also other important parameters, the release and combustion of volatile compounds and the combustion of the high ash content, may potentially affect the overall combustion process of SS. To control other parameters, a maximum SS feed rate of $5 \%$ of the clinker production capacity was suggested by Aranda Usón et al. (2013).

\subsection{Factor affecting indirect emissions}

\subsubsection{Electricity emission factor}

Electrical production of China has long been based on coal-fired electricity generation. Other power sources, such as hydropower, nuclear power, and wind power, are relatively clean. Thus, China's electricity emission factor is based on power coal intensity. Yu et al. (2014) utilized life-cycle assessment to assess the effect of carbon emissions and calculated the coefficient of carbon emissions in coal-to-energy chains. In this study, 4 processes (coal mining, selecting and washing, transport and electricity generation) were calculated to estimate the GHG emissions. Results show that the carbon emissions coefficient of coal to energy chain in China is $875 \mathrm{~g} / \mathrm{kWh}$. So, lowering the percentage of coal-fired electricity, enhancing coal mining energy conservation, increasing the proportion of railway transportation in coal transportation and improving energy-power conversion efficiency are the main ways to decrease electricity emission factor.

\subsubsection{Electricity consumption}

Electricity is used in the cement production process for raw materials extraction, blending, grinding, homogenization, clinker production, cement grinding and convey, packing and loading. $\mathrm{Gu}$ et al. (2012) reported that average electrical energy consumption was about $110 \mathrm{kWh} / \mathrm{t}$ cement in China's cement industry. Grinding remains the biggest source of energy consumption in cement production. Approximately $60-70 \%$ of the total electrical energy is used for the grinding of raw materials, coal and clinker. So, the use of new grinding equipment is the main way to reduce power consumption in cement production, and an important method to reduce $\mathrm{CO}_{2}$ emissions. Vertical mill and roller mill have about 30\% energy saving than ball mill (Ali et al., 2011). Adoption and utilization of waste heat recovery (WHR) power generation technology is another way to reduce China's cement energy intensity. In the year of 2011, the installed capacity of WHR power generation reached 4786 megawatts (MW) (Zuo and Yang, 2011). Ke et al. (2013), based on the clinker production, assumed that $36 \mathrm{kWh}$ electricity was generated by the production progress of per ton clinker, which can typically provide $25-33 \%$ of a cement facility's electricity demand for cement production (Zeng, 2009). Other equipments, such as high-efficiency classifiers, high efficiency motors and frequency implementations are also used for decrease electricity consumption and reduce $\mathrm{CO}_{2}$ emissions.

\section{Conclusions}

Cement production as one of main sources of $\mathrm{CO}_{2}$ emissions has received worldwide concern. China is the biggest producer and $\mathrm{CO}_{2}$ emitter in cement industry. Thus the cement industry is a critical sector in China to meet its national $40-45 \%$ carbon intensity reduction target. Conventional cement emission factor can be used to evaluate roughly national/regional cement emissions, but it ignores some changing facets like the alternative materials used in clinker production, low clinker to cement ratio, and other factors. After onsite empirical studies we argued that the estimations by the conventional emission factor might overestimate the actual state. The input method, TC method, and regional electricity emission factor based on 15 collected cement plants are applied to compare the discrepancies of three different emissions with traditional method. The input method based on the three elements, $\mathrm{CaO}$ and $\mathrm{MgO}$ content in carbonate-containing material, materials ratio in raw meal, and raw meal clinker mass ratio are some reasonable parameters to measure the process emission in clinker production by getting rid of the $\mathrm{CaO}$ and $\mathrm{MgO}$ content in non-carbonate materials. It helps provide more insights about alternative material use and clinker quality changes in cement production, and can be applied to many other countries in the world.

This article reports the $\mathrm{CO}_{2}$ emission results of onsite cement plants in China. Accordingly, almost all of the process emissions by the input method are lower than those by the output method. About $13 \mathrm{~kg}$ and $11 \mathrm{~kg}$ process emissions based on input method are lower than output method for NSP kiln and shaft kilns, respectively. This comparative result shows that $\mathrm{CaO}$ and $\mathrm{MgO}$ in clinker are not in the form of carbonate materials, and the output method magnifies $\mathrm{CO}_{2}$ emissions by the $\mathrm{CaCO}_{3}$ and $\mathrm{MgCO}_{3}$ decompose. Therefore, we strongly suggest to calculate clinker process emission with $\mathrm{CO}_{2}$ content in raw meal and raw meal clinker mass ratio. The $\mathrm{CO}_{2}$ content in raw meal is estimated by the $\mathrm{CaO}$ and $\mathrm{MgO}$ content in carbonate-containing material and their material ratio to calculate $\mathrm{CO}_{2}$ content in raw meal; and the plant-specific raw meal clinker mass ratios based on the principle of mass balance is $1.51 \mathrm{t}$, lower than CSI default value ( $1.55 \mathrm{t}$ ). Compared with fuels emissions from collected plants, all fuel emissions based on LHV method is higher than that of TC method. Thus, CSI encourages companies to use TC content method in calculating plant-specific fuels emissions. Regional electricity emission factor are used to evaluate the indirect emissions from cement production; and the values indicate that there is no significant discrepancy of electricity emissions per ton clinker/cement in raw meal preparation and cement grinding stage, 
while this emissions are observably different in clinker production stage for NSP kilns and shaft kilns. According to the analysis, we conclude that replace carbonate-containing materials with noncarbonate materials is the main way to reduce calcining emissions, and the reduction potential of process emissions by adjusting clinker quality is limited $(\leq 6 \%)$. Application of advanced kiln, efficiency equipments and technologies to decline fuel intensity, and adopting lower carbon content fuel are two main way to reduce the fuel emissions in cement production. Lower electricity emission factor and consumption by using more efficiency electrical facilities and recycling waste energy means lower indirect emissions.

The cement industry is a high pollutant emitting industry. From above comparison we found that the input method can reasonably and reliably represents actual process emission in present production situation, and can be widely used in other production lines. This method may be of interest for future studies to discuss the sensitivity of each input variables towards low process emissions. TC method is encouraged by international organization to calculate fuel emissions. Using more efficiency electrical facilities and recycling waste energy could decrease electricity consumption in cement production. The analysis of some major affecting factor for $\mathrm{CO}_{2}$ emissions provides quantitative information to improve the production technology, use alternative resource and energy, and suggest policy-makers to set up more sustainable development strategy for cement industry.

\section{Acknowledgments}

This work is financially supported by 1) the Strategic Priority Research Program-Climate Change: Carbon Budget and Related Issues of the Chinese Academy of Sciences (XDA05010400), 2) China Postdoctoral Science Foundation (2014M550819), 3) National Natural Science Foundation of China (41271547), 4) Central Universities Basic Scientific Research Special Fund, China (201208905), 5) Resources and Environment Economy Research Center Open Fund of China University of Geosciences, Wuhan (G20122007B), 6) China Scholarship Council (201306415013). The authors thank all anonymous reviewers for their valuable comments and suggestion.

\section{References}

Ali, M.B., Saidur, R., Hossain, M.S., 2011. A review on emission analysis in cement industries. Renew. Sustain. Energy Rev. 15, 2252-2261.

Ammenberg, J., Baas, L., Eklund, M., Feiz, R., Helgstrand, A., Marshall, R., 2014. Improving the $\mathrm{CO}_{2}$ performance of cement, part III: the relevance of industrial symbiosis and how to measure its impact. J. Clean. Prod. 98, 272-281. http://dx. doi.org/10.1016/j.jclepro.2014.1001.1086.

Aranda Usón, A., López-Sabirón, A.M., Ferreira, G., Llera Sastresa, E., 2013. Uses of alternative fuels and raw materials in the cement industry as sustainable waste management options. Renew. Sustain. Energy Rev. 23, 242-260.

Barker, D.J., Turner, S.A., Napier-Moore, P.A., Clark, M., Davison, J.E., 2009. CO capture in the cement industry. Energy Proced. 1, 87-94.

Boden, T.A., Marland, G., Andres, R.J., 2009. Global, Regional, and National Fossil-fuel $\mathrm{CO}_{2}$ Emissions. Carbon Dioxide Information Analysis Center, Oak Ridge National Laboratory, U.S. Department of Energy, Oak Ridge, Tenn., U.S.A. http://dx.doi. org/10.3334/CDIAC/00001.

Cascarosa, E., Gasco, L., Gea, G., Sánchez, J.L., Arauzo, J., 2011. Co-gasification of meat and bone meal with coal in a fluidised bed reactor. Fuel 90, 2798-2807.

CDICA, 2013. Fossil-fuel $\mathrm{CO}_{2}$ Emissions.

Chen, W., Hong, J., Xu, C. 2015. Pollutants generated by cement production in China, their impacts, and the potential for environmental improvement. J. Clean. Prod. 103, 61-69. http://dx.doi.org/10.1016/j.jclepro.2014.04.048.

$\mathrm{CMBA}, 2011$. Calculation Method of $\mathrm{CO}_{2}$ Emission with Cement Production.

CSI, 2005. Guidelines for the Selection and Use of Fuels and Raw Materials in the Cement Manufacturing Process.

CSI, 2011. The Cement $\mathrm{CO}_{2}$ and Energy Protocol (Version 3). Washington, US, p. 23.

Cui, S.P., Liu, W., 2008. Analysis of $\mathrm{CO}_{2}$ emission mitigation potential in cement producing processes. China Cem. 4, 57-59.

Deja, J., Uliasz-Bochenczyk, A., Mokrzycki, E., 2010. CO 2 emissions from Polish cement industry. Int. J. Greenh. Gas Control 4, 583-588.
EPA, 2008. Climate Leaders Greenhouse Gas Inventory Protocol Core Module Guidance: Direct Emissions from Stationary Combustion Sources. Office of Air and Radiation, Washington, DC.

Fan, D.-J., Yang, Z.-S., Mao, D., Guo, Z.-G., 2001. Clay minerals and geochemistry of the sediments form the Yangtze and Yellow Rivers. Mar. Geol. Quat. Geol. 21, $7-12$.

Feiz, R., Ammenberg, J., Baas, L., Eklund, M., Helgstrand, A., Marshall, R., 2015. Improving the $\mathrm{CO}_{2}$ performance of cement, part II: framework for assessing $\mathrm{CO}_{2}$ improvement measures in the cement industry. J. Clean. Prod. 98, 282-291. http://dx.doi.org/10.1016/j.jclepro.2014.1001.1103.

Gu, A., Shi, X., Wang, L., Zhao, X., 2012. The potential and cost analysis of energy saving and emission reduction in China cement sector. China Popul. Resour. Environ. 8, 16-21.

Gulyurtlu, I., Boavida, D., Abelha, P., Lopes, M.H., Cabrita, I., 2005. Co-combustion of coal and meat and bone meal. Fuel 84, 2137-2148.

Hu, D., Guo, Z., Wang, Z., Xiao, Q., 2014. Metabolism analysis and eco-environmental impact assessment of two typical cement production systems in Chinese enterprises. Ecol. Inform. http://dx.doi.org/10.1016/j.ecoinf.2014.05.008.

IPCC, 1996. IPCC Guidelines for National Greenhouse Gas Inventories.

IPCC, 2006. 2006 IPCC Guidelines for National Greenhouse Gas Inventories. Cambridge University Press, Cambridge, United Kingdom and New York, NY, USA.

Ke, J., McNeil, M., Price, L., Khanna, N.Z., Zhou, N., 2013. Estimation of $\mathrm{CO}_{2}$ emissions from China's cement production: methodologies and uncertainties. Energy Policy 57, 172-181.

Ke, J., Zheng, N., Fridley, D., Price, L., Zhou, N., 2012. Potential energy savings and $\mathrm{CO}_{2}$ emissions reduction of China's cement industry. Energy Policy 45, 739-751.

Krammart, P., Tangtermsirikul, S., 2004. Properties of cement made by partially replacing cement raw materials with municipal solid waste ashes and calcium carbide waste. Constr. Build. Mater. 18, 579-583.

Lei, Y., Zhang, Q., Nielsen, C., He, K., 2011. An inventory of primary air pollutants and $\mathrm{CO}_{2}$ emissions from cement production in China, 1990-2020. Atmos. Environ. 45, 147-154.

Li, C., Nie, Z., Cui, S., Gong, X., Wang, Z., Meng, X., 2014. The life cycle inventory study of cement manufacture in China. J. Clean. Prod. 72, 204-211.

Lindner, S., Liu, Z., Guan, D., Geng, Y., Li, X., 2013. CO2 emissions from China's power sector at the provincial level: consumption versus production perspectives. Renew. Sustain. Energy Rev. 19, 164-172.

Liu, J., Li, H., 2010. Developing low-carbon economy promotes the cement industry changes. China Resour. Compr. Util. 28, 56-58.

Ma, Z.-p., Huang, J.-z., Zhang, H., 2005. Chemical weathering of carbonate cement in standstone and the related cultural relic diseases in Yungang Grottoes. Carsologica Sin. 1, 71-76.

Martín-Sedeño, M.C., Cuberos, A.J.M., De la Torre, Á.G., Álvarez-Pinazo, G. Ordónez, L.M., Gateshki, M., Aranda, M.A.G., 2010. Aluminum-rich belite sulfoaluminate cements: clinkering and early age hydration. Cem. Concr. Res. 40, 359-369.

Mikulčić, H., Vujanović, M., Duić, N., 2013. Reducing the $\mathrm{CO}_{2}$ emissions in Croatian cement industry. Appl. Energy 101, 41-48.

Mikulčić, H., Vujanović, M., Duić, N., 2015. Improving the sustainability of cement production by using numerical simulation of limestone thermal degradation and pulverized coal combustion in a cement calciner. J. Clean. Prod. 88, 262-271. http://dx.doi.org/10.1016/j.jclepro.2014.1004.1011.

Mokrzycki, E., Uliasz-Bocheńczyk, A., 2003. Alternative fuels for the cement industry. Appl. Energy 74, 95-100.

NBS, 2012a. China Energy Statistical Yearbook 2012. China Statistics Press, Beijing.

NBS, 2012b. China Industry Economy Statistical Yearbook 2012. China Statistics Press, Beijing.

NDRC, National Development and Reform Commission, 2004. The People's Republic of China Initial National Communications on Climate Change. China Planning Press, Beijing.

NDRC, 2012. Baseline Emission Factors for Regional Power Grids in China.

NMBTC CMBA, 2007. Shaft Kiln System Thermal Detection Evaluation for Shandong Luzhong Cement Plant.

Oh, D.-Y., Noguchi, T., Kitagaki, R., Park, W.-J., 2014. CO 2 emission reduction by reuse of building material waste in the Japanese cement industry. Renew. Sustain. Energy Rev. 38, 796-810.

Pardo, N., Moya, J.A., Mercier, A., 2011. Prospective on the energy efficiency and $\mathrm{CO}_{2}$ emissions in the EU cement industry. Energy 36, 3244-3254.

PBL, 2008. Global $\mathrm{CO}_{2}$ Emissions: Increase Continued in 2007.

Pelletier-Chaignat, L., Winnefeld, F., Lothenbach, B., Müller, C.J., 2012. Beneficial use of limestone filler with calcium sulphoaluminate cement. Constr. Build. Mater. 26, 619-627.

Qiu, X., Wang, L., Liu, D., Cheng, Y., 2012. The accounting and monitoring $\mathrm{CO}_{2}$ emissions from cement production. China Cem. 12, 66-68.

Rattanashotinunt, C., Thairit, P., Tangchirapat, W., Jaturapitakkul, C., 2013. Use of calcium carbide residue and bagasse ash mixtures as a new cementitious material in concrete. Mater. Des, 46, 106-111.

Rovira, J., Mari, M., Nadal, M., Schuhmacher, M., Domingo, J.L., 2010. Partial replacement of fossil fuel in a cement plant: risk assessment for the population living in the neighborhood. Sci. Total Environ. 408, 5372-5380.

Shen, L., Gao, T., Zhao, J., Wang, L., Wang, L., Liu, L., Chen, F., Xue, J., 2014. Factorylevel measurements on $\mathrm{CO}_{2}$ emission factors of cement production in China. Renew. Sustain. Energy Rev. 34, 337-349. 
Tu, H., Chen, Y., Chen, W., 2003. Fixed carbon applied to calculated carbon content of anthracite coal in China. Coal Sci. Technol. 12, 98-100.

Van Oss, H., Padovani, A.C., 2002. Cement manufacture and the environment: part I: chemistry and Technology. J. Ind. Ecol. 6, 89-106.

Wang, J., 2006. Technical Research on Incinerating Living Waste with NSP. Xi'an University of Architecture and Technology, Xi'an.

Wang, L., 2008. Further discussion of $\mathrm{CO}_{2}$ emission reduction in Chinese cement industry. China Cem. 36-39.

Wang, L., 2009. Estimation of $\mathrm{CO}_{2}$ emissions from cement plants. China Cem 7 21-22.

Wang, Y., Zhu, Q., Geng, Y., 2013. Trajectory and driving factors for GHG emissions in the Chinese cement industry. J. Clean. Prod. 53, 252-260.

WBCSD, World, 2002. Business Council for Sustainable Development. Toward a sustainable cement industry. http://www.wbcsd.org/web/publications/batellefull.pdf.

Worrell, E., Price, L., Martin, N., Hendriks, C., Meida, L.O., 2001. Carbon dioxide emissions from the global cement industry. Ann. Rev Energy Environ 26, 303-329.
Xu, J.-H., Fleiter, T., Eichhammer, W., Fan, Y., 2012. Energy consumption and $\mathrm{CO}_{2}$ emissions in China's cement industry: a perspective from LMDI decomposition analysis. Energy Policy 50, 821-832.

Yu, S., Wei, Y.-M., Guo, H., Ding, L., 2014. Carbon emission coefficient measuremen of the coal-to-power energy chain in China. Appl. Energy 114, 290-300.

Zeng, X., 2009. Development report of cement industry waste heat power generation. China Cem. 10, 18-23.

Zhang, B., 2008. The application of leather as an alternative fuel in cement production line (5000t/d). Cement 8, 17-19.

Zhou, Q., Huang, Q., Qi, W., Li, L., 2009. LCA on co-processing waste leather in cement kilns. Res. Environ. Sci. 22, 506-510.

Zhu, S.L., 2000. GHG emissions of cement industry and the measures to reduce emission. China Energy 7, 25-28.

Zuo, S.-Y., 1981. Iron carbonate chemical phase analysis in iron ore. Hunan Metall 5 50-57.

Zuo, Z., Yang, M., 2011. Thoughts on energy conservation of China cement industry during the "Twelfth Five Years Plan". China Cem. 7, 10-12. 